\section{Sedimentation in Loch Earn and Loch Lubnaig, Scotland}

IN their paper about sedimentary features associated with slumping in Loch Earn and Loch Lubnaig, McManus and Duck ${ }^{1}$ indicate that there is no prior record of the use of sonar devices in lakes for the investigation of "subaqueous landforms". This is a curious statement given our ${ }^{2}$ earlier reported work in their own field area and the extensive surveys of the Canadian Centre for Inland Waters in for example, the Great Lakes (see ref. 3), where acoustic techniques have become standard for mapping both lakebed and sub-bottom landforms, whose recognition is regarded as a normal prerequisite for any engineering undertaking.

While McManus and Duck ${ }^{1}$ recognize that their observed slumps occur at depths below the influence of surface water waves, they do not consider the possibility that longer period waves, such as seiches or internal waves, may influence bed forms. It is instructive to investigate the theoretical seiche 4 for any lake under sedimentological investigation to see if water velocities expected at the lakebed may be great enough to cause sediment movement. I have done this for a water body of rectangular cross-section (length $2,500 \mathrm{~m}$, depth $30 \mathrm{~m}$ ) as a crude model of the Stank Basin ${ }^{5}$ of Loch Lubnaig and conclude that a water particle velocity of $5 \mathrm{~cm} \mathrm{~s}^{-1}$ is possible for a seiche of only $0.1-\mathrm{m}$ amplitude, the period of oscillation being $\sim 5 \mathrm{~min}$. Seiche observations by Gill $^{6}$ on Llyn Gwellyn, a lake of comparable size to the Stank Basin, suggest that a real seiche would be of longer period than the approximate theory predicts, but that particle velocities at the base of the water column would still be sufficient to transport silts and finer grains (Graf and Acaroglu ${ }^{7}$ ) even if the seiche amplitude were only a few centimetres. $\mathrm{We}^{2}$ have observed three sediment waves or mounds in the bed of the Stank Basin. They rise, with gradients of $1: 5$, to a height of $5 \mathrm{~m}$ above the general level of the fine lakebed sediment, which is itself no more than $5 \mathrm{~m}$ thick. The sediment waves are symmetrical and show layering which parallels the sediment-water interface. Such layering and symmetry would not arise from slumping, but could be produced by a seiche-driven oscillatory water current. McManus and Duck ${ }^{1}$ have drawn attention to the effect that sediment disturbance from slumping will have on the interpretation of lakebed sediment cores retrieved for palaeomagnetic or palaeoecological purposes. Disturbance in the manner I propose will be a more subtle effect because of the presence of seemingly undisturbed layers.

In Scottish lochs, the use of modern acoustic equipment (with the exception of its largely ludicrous use in Loch Ness) has been neglected. This is not the tribute that Murray and Pullar ${ }^{7}$ would have wished. As well as conventional sidescan and profiling records, sediment acoustic velocity determinations are required ${ }^{8,9}$ to help assign proper depth scales and to assess sediment gas content, cited by Monroe ${ }^{10}$ as an important factor in causing slumping. I hope that McManus and Duck ${ }^{1}$ and others will receive support to extend their work to other lochs and perhaps to map more completely the mounds in the Stank Basin and to verify if they are indeed associated with seiche activity induced by the winds howling down the glen at Ardchullarie Mor.

Atlantic Geoscience Society,

35 Edward Street, Dartmouth,

Nova Scotia, Canada B2Y 2PC

1. McManus, J. \& Duck, R. W. Nature 303, 161-162 (1983), 2. McKay, A. G. \& McEwen, I. J. Mar. Sedim Allantic Geol 18, 58 (1982).

3. Thomas, R. L., Demp, A. L. \& Lewis, C. F. M. Can. Eanh Sci. 10, 226-271 (1973)

4. Neumann, G. \& Pierron, W. J. Principles of Physical Oceanography, 291 (Prentice-Hall, Englewood Clifts, 1966).

5. Gill, W. W. S. thesis, Univ. Coll. North Wales (1967)

6. Gral, W. H. \& Acaroglu, E. R. Bull. Ine Ass Sci. Hydrol $11,27-43$ (1966).

7. Murray, J. \& Pullar, L. Bashymetric Survey of the Scontish Freshwater Lochs (Challenger Office, Edinburgh, 1910). 8. Bell, D. L. \& Porter, W. J. in Physics of Sound in Marine Sediments (ed. Hampton, L.) (Plenum, New York. 1974).

9. McKay. A. G. \& McKay, P. M. J. acouse Soc. Am. 71 . 871-878 (1982).

10. Monroe, J. N. Science 161, 1394-1395 (1969).

DUCK AND MCMANUS REPLY-We welcome the comments of McKay concerning our recent contribution ${ }^{1}$. He is correct to draw attention to sonar work in the North American Great Lakes. In view of their enormity these water bodies behave as inland seas and are not directly comparable with even the largest of the Scottish lochs.

Our contribution ${ }^{1}$ specifically referred to sidescan sonar surveys and not to the use of sonar devices in general. The principal work reported was undertaken on Loch Earn and mention was made of Loch Lubnaig to illustrate that the subaqueous landforms recognized are not mere curiosities confined to one water body. We have since detected them in other lochs.

We were unaware of the boomer seismic work of McKay and McEwen ${ }^{2}$ in Loch Lubnaig as their brief abstract was published in a Canadian journal not known for its contributions to Scottish environmental studies. The report of sediment waves or mounds in the Stank Basin ${ }^{2}$ is interesting but, despite re-examination of sonographs and echograms ${ }^{3}$, we have been unable to confirm their presence due to lack of information regarding their position or orientation. However, marginal spurs are recognized extending into the basin floor from the bounding slopes.

Seiches or internal waves may indeed influence loch bedforms. However, as yet, we have insufficient hydrodynamic data to corroborate this. Furthermore we have reservations about the seiche-associated current velocities calculated by McKay for Loch Lubnaig. Although we have not undertaken seiche observations in the loch there is good reason to believe that the $0.1-\mathrm{m}$ surface seiche amplitude used in McKay's model, and to which the horizontal current velocity is proportional ${ }^{4}$, is excessively large. Chrystal ${ }^{5}$ demonstrated that seiche activity is poorly developed in Loch Lubnaig due to its shallow nature (mean depth, $13 \mathrm{~m}$ ), its very irregular bottom and its orientation across the path of atmospheric disturbances. During a 6week period only four instances of definite, but short-lived, seiche activity, with a period of about $24 \mathrm{~min}$, were recognized $^{5}$. For most of the period "...nothing was found but wind embroidery and sub-permanent wind denivellation, such as would be naturally expected in a shallow lake"s. Moreover, the maximum seiche amplitude observed by Chrystal $^{5}$ (Fig. 22) was only about $0.5 \mathrm{~cm}$. On the basis of McKay's model for the Stank Basin the maximum current velocity, at a seiche node, associated with such activity would be less than $0.3 \mathrm{~cm} \mathrm{~s}^{-1}$. Average current velocities would be about half this value and tend to die away rapidly with time ${ }^{6}$. Thus currents resulting from surface seiches are unlikely to be responsible for the bedforms described.

To our knowledge the thermal behaviour of Loch Lubnaig has not been investigated. However, it is likely that internal wave (internal seiche ${ }^{7}$ ) activity will occur in association with summer stratification. Horizontal current velocity components generated by such water movements are known to be up to five times greater than those associated with corresponding surface seiches ${ }^{8.9}$. Moreover, these currents can persist for several days ${ }^{8}$. Hence it is possible that internal waves may have a role in the formation of the structures recognized by McKay and McEwen ${ }^{2}$, perhaps in the manner advocated by Mortimer ${ }^{10}$.

\section{Department of Geology,}

ROBERT W. DUCK JOHN MCMANUS

The University, Dundee DD1 $4 H N$, UK

1. McManus, J. \& Duck, R. W. Nature 303, 161-162 (1983) 2. McKay, A. G. McEwen, I. J. Mar. Sedim. Atlantic Geol. 18. 58 (1982).

3. Asand, N. M. thesis, Univ. Dundee (1982)

4. Proudman, J. Dynamical Oceanography (Wiley, London. 1953). 
5. Chrystal. G. in Bathymetrical Survey of the Scottish Fresh water Lochs Vol. 1, 29-90 (Challenger Ofice, Edin burgh, 1910).

6. Smith, 1. R. Freshwater Biol 9, 119-145 (1979).

7. Wilson, B. W. Adv. Hydrosci. 8, 1-94 (1972)

8. George, D. G. Freshwat Biol. 11, 37-60 (1981).

9. Duck, R. W. thesis, Univ. Dundee (1982).

10. Mortimer, C. H. Phil. Trans. R. Soc. B236, 355-404 (1952).

\section{Control of fertility in red deer}

LOUDON ET AL. ${ }^{1}$ have recently invoked a suckling-mediated mechanism for the control of fertility in red deer hinds. We suggest that their emphasis on the role of prolactin is not justified by their data and that other explanations are equally likely.

Although plasma prolactin concentrations are positively associated with the frequency of suckling ${ }^{2}$, the authors fail to show a significantly higher plasma prolactin level after 80 days, between groups of hinds on low versus high planes of nutrition, despite the persistence of high suckling frequencies in the former. There is a minimum lag of some $\mathbf{3 0}$ days separating this latest detection of a difference in plasma prolactin levels between the groups and the earliest possible conception on day 110 - when the stag was introduced. It is questionable as to whether there would be an ovulation-inhibiting effect of increased plasma prolactin levels this far in advance of ovulation, even if, as has been suggested ${ }^{3}$, such an effect were to operate on the follicular stage of the 18.3 day oestrous cycle ${ }^{4}$. This is assuming that prolactin has a causal influence on oestrus cycle activity which itself remains in doubt ${ }^{5}$.

Loudon et al. do not attempt to separate from the suckling data the confounding effect of differences in mean body weight between the two groups. It is well established that body weight not only influences fertility rates but may also affect the onset of oestrus in mammais ${ }^{6}$. In farmed red deer small hinds calve later than heavy hinds: a $1 \mathrm{~kg}$ increase advancing calving by between 0.3 and 1.0 days (ref. 7 and A.S.I. Loudon, personal communication). Furthermore, in the wild the average nonlactating hind calves approximately 2 days earlier for every $1 \mathrm{~kg}$ increase in mean autumn body weight ${ }^{8}$. Therefore a $4.1 \mathrm{~kg}$ difference in mean body weights between the two groups could explain the 6.5 day difference in return to oestrus and could be tested with their data. However, even if this is plausible and weight for weight hinds on a low nutritional plane return to oestrus later, this may be for reasons other than lactational control. For example, it is well known that in sheep, which cease lactation many weeks before the rut, body condition interacts with the plane of nutrition immediately before breeding ${ }^{9}$. At a given weight individuals that are rapidly improving in condition, as might be expected in the group of hinds on permanent grass pasture, show earlier ovulation and higher ovulation rates.

In summary, Loudon et al. concur with at least one other study in failing to show any influence of the plane of nutrition on plasma prolactin levels during or immediately before the onset of the reproductive period $^{10}$. As a consequence, they have little reason to invoke elevated levels of prolactin as a mechanism delaying conception in poorly nourished hinds. Finally, by not controlling in any way for maternal body weight and/or condition, the major confounding variable is not eliminated nor its contribution to the observed effect even brought into question.

S. D. ALBON

G. R. IASON

Large Animal Research Group,

Department of Zoology,

University of Cambridge,

Downing Street,

Cambridge CB2 3EJ, UK

1. Loudon, A. S. 1., McNeilly, A. S. \& Milne, J. A. Nature 302, 145-147 (1983).

2. McNeilly, A. S. Br. med. Bull. 35, 151-154 (1979)

3. McNeilly, A. S., Glasier, A.. Jonassen. J. \& Howie, P. W. J. Reprod. Fer. 65, 559-569 (1982).

4. Guinness. F. E., Lincoln, G. A. \& Short. R. V. J. Reprod. Fert. 27, 427-438 (1971).

5. Webster, G. M. \& Haresign, W. J. Reprod. Fert. 67, 465471 (1983)

6. Ssdleir. R. M. F. S. The Ecology of Reproduction in Wild and Domestic Mammals (Methuen, London. 1969).

7. Hamilton, W. J. \& Blaxter, K. L. J. agric. Sci, Camb. 95 261-273 (1980)

8. Mitchell, B. \& Lincoln. G. A. J. Zool. 171, 141-152 (1973) Gunn, R. G. \& Daney, J. N. J. agric. Sci., Camb. 85, 465-470 (1975)

10. Rhind, S. M. Robinson, J. J., Chesworth, J. M. \& Crolts, R. M. J. J. Reprod. Fen. 58, 145-152 (1980)

LOUDON ET AL. REPLY-In our paper we drew attention to the influence of pasture type on the milk yield, suckling patterns and fertility of red deer hinds. We were alerted to the physiological implications of the differences in suckling pattern when we considered our data on prolactin. These data, in common with a number of other studies, showed that prolactin levels were correlated with suckling frequency. At no point in our paper did we suggest that prolactin per se was ultimately involved in the regulation of fertility in red deer. Indeed we would suggest that in seasonally breeding mammals such as deer and sheep prolactin may have little influence on fertility. Thus, sheep treated with bromocriptine to block the normal high levels of prolactin in mid-summer resumed fertility at an identical time to untreated control sheep $p^{1.2}$. Thus although prolactin may have an important function in regulating fertility in some mammals including humans, we agree with Albon and lason that there is little evidence that it may be directly important in the case of red deer.

We know of only one study that attempted to control female weight, food intake, milk yield and offspring growth rate while manipulating suckling frequency. In this study, ewes compelled to suckle their offspring twice a day resumed oestrous activity at an earlier date than those permitted to suckle five times a day ${ }^{3}$. We acknowledge that there is clear evidence that the body condition of non-lactating sheep prior to mating has an effect on their fertility but suggest that in the cases of wild mammals, including red deer, which, unlike sheep, frequently suckle their offspring through the mating period, the pattern of suckling activity may have a profound effect on their subsequent fertility. Body weight per se, like prolactin, simply correlates with differences in return to oestrus in red deer. We are unable to attribute differences in body weight between the two groups of hinds to differences in body condition or differences in gut fill associated with the complex effects of grazing different grass pastures.

\section{A. S. I. LOUDON}

Institute of Zoology,

Regents Park,

London NW1 4RY, UK

A. S. MCNEILLY

MRC Reproductive Biology Unit,

Centre for Reproductive Biology,

37 Chalmers Street,

Edinburgh EH3 9EW, UK

J. A. MILNE

Hill Farming Research Organisation,

Bush Estate, Penicuik,

Midlothian EH26 OPY, UK

1. Fitzgerald, B. P. \& Cunningham, F. J. J. Reprod. Fen. 61 , 141-148 (1981)

2. Land, R. B. Carr, W. R. McNeilly, A. S. \& Preece, R. D. J. Reprod. Fert. 59, 73-78 (1980).

3. Dingwall, W. S., Robinson, J. S. \& Atkinson, T. Anim Prod. 34, 370 (1982)

\section{Matters Arising}

Matters Arising is meant as a vehicle for comment and discussion about papers that appear in Nature. The originator of a Matters Arising contribution should initially send his manuscript to the author of the original paper and both parties should, wherever possible, agree on what is to be submitted. Neither contribution nor reply (if one is necessary) should be longer than 500 words and the briefest of replies, to the effect that a point is taken, should be considered. 